\title{
Satisfaction and dissatisfaction in the work of recyclable solid waste segregators: convergent-care research
}

\author{
Satisfação e insatisfação no trabalho de catadoras de materiais recicláveis: estudo convergente-assistencial \\ Satisfacción e insatisfacción en el trabajo de recuperadoras de materiales reciclables: \\ estudio convergente asistencial
}
Alexa Pupiara Flores Coelho', Carmem Lúcia Colomé Beck', Rosângela Marion da Silva', Francine Cassol Prestes', Silviamar Camponogara', Anahlú Peserico'

' Universidade Federal de Santa Maria, Postgraduate Program in Nursing. Santa Maria, Rio Grande do Sul, Brazil.

How to cite this article:

Coelho APF, Beck CLC, Silva RM, Prestes FC, Camponogara S, Peserico A. Satisfaction and dissatisfaction in the work of recyclable solid waste segregators: convergent-care research.

Rev Bras Enferm [Internet]. 2017;70(2):384-91. DOI: http://dx.doi.org/10.1590/0034-7167-2016-0325

Submission: 06-20-2016 Approval: 11-13-2016

\begin{abstract}
Objectives: describe elements that promote satisfaction and dissatisfaction in the work of recyclable solid waste segregators and conduct a nursing action focused on these elements. Method: qualitative research, convergent-care, conducted with members of the cooperative. Data production occurred during 2015 through participation observation, semi-structured interviews, and a convergence group. Analysis comprised the phases Apprehension, Synthesis, Theorization, and Transference. Results: four categories emerged. They showed satisfaction and dissatisfaction related to identification with tasks and work content, material and personal gains obtained from solid waste segregation, prejudice, lack of appreciation, and difficulties in interpersonal relationships. This last item, due to its importance, received a nursing action. Conclusion: the study contributed to the advancement of knowledge and the association of possibilities between the research performance and nursing care for workers. Descriptors: Nursing; Workers' Health; Solid Waste Segregators; Job Satisfaction; Qualitative Research.
\end{abstract}

\section{RESUMO}

Objetivos: descrever os elementos promotores de satisfação e insatisfação no trabalho de catadoras de materiais recicláveis e realizar uma ação de enfermagem focada nesses elementos. Método: pesquisa qualitativa, convergente-assistencial, realizada com catadoras cooperativadas. A produção de dados ocorreu em 2015 por meio de observação participante, entrevistas semiestruturadas e grupo de convergência. A análise contemplou as fases Apreensão, Síntese, Teorização e Transferência. Resultados: emergiram quatro categorias que ilustram vivências de satisfação e insatisfação relacionadas à identificação com as tarefas e com o conteúdo do trabalho, ganhos materiais e pessoais obtidos com a catação, o preconceito, a desvalorização e dificuldades nas relações interpessoais. Esta última, devido ao seu destaque, foi objeto de uma ação de enfermagem. Conclusão: o estudo contribuiu para o avanço de conhecimentos e possibilidades de associação entre a realização da pesquisa e do cuidado de enfermagem com trabalhadores.

Descritores: Enfermagem; Saúde do Trabalhador; Catadores; Satisfação no Emprego; Pesquisa Qualitativa.

\section{RESUMEN}

Objetivos: describir los elementos promotores de satisfacción e insatisfacción en el trabajo de recuperadoras de materiales reciclables y realizar acción de enfermería enfocada en tales elementos. Métodos: estudio cualitativo, convergente asistencial, realizado con recuperadoras trabajando en cooperativa. Datos obtenidos en 2015 mediante observación participante, entrevistas semiestructuradas y grupo de convergencia. El análisis contempló las fases Aprendizaje, Síntesis, Teorización y Transferencia. Resultados: emergieron cuatro categorías que ilustran experiencias de satisfacción e insatisfacción relativas a la identificación con las tareas y el contenido del trabajo, ganancias materiales y personales obtenidas con la recuperación, el prejuicio, la desvalorización y dificultades con las relaciones interpersonales. Esta última, por su significatividad, fue objeto de una acción 
de enfermería. Conclusión: el estudio contribuyó a mejorar conocimientos y posibilidades de asociación entre la realización de la investigación y la atención de enfermería a trabajadores.

Descriptores: Enfermería; Salud Laboral; Segregadores de Residuos Sólidos; Satisfacción en el Trabajo; Investigación Cualitativa.

\section{CORRESPONDING AUTHOR}

\section{INTRODUCTION}

Job satisfaction is an element that determines human health and full development. When workers are capable of conducting their practice with pleasure, living with feelings of recognition and appreciation for their actions, their work environment becomes a place for personal growth and realization. In this sense, as workers become capable of recognizing the elements that give them satisfaction or dissatisfaction in their professional activity, they can optimize their awareness of their own importance and belonging, thus making their work experience more pleasurable ${ }^{(1)}$.

Although the relationship between job satisfaction and the health of individuals is scientifically recognized, there still are gaps to be filled. One of them pertains to the little attention that has been directed to the multidimensional aspects of job satisfaction; another includes the small number of studies that consider work health a result of the articulation between physical and psychic factors ${ }^{(2)}$.

It is worth comprehending job satisfaction and dissatisfaction in different contexts, such as cooperatives where recyclable solid waste segregators work daily. These individuals are a difficult group to reach; they are stigmatized and, frequently, living in situations of extreme poverty ${ }^{(3)}$. The informal nature of their workplaces them in a situation of social vulnerability, because they do not have labor and welfare benefits most of the time ${ }^{(4)}$. Moreover, segregators frequently do not receive social recognition for their work and suffer prejudice and neglect from government, society, and their families due to the stigma of constantly working with what was discarded, the waste w $^{(4-5)}$.

The recyclable solid waste segregator's activity is usually performed under precarious work conditions and pay. However, it is considered by them as a way to avoid unemployment ${ }^{(6)}$. Research shows that, for some segregators, their work is ambiguous, meaning that they emphasize both the positive and negative aspects imposed by daily difficulties, alternating feelings of satisfaction and of suffering ${ }^{(4)}$. This reinforces the paradoxical character of the occupation, which can bring both health and disease, pleasure and suffering, satisfaction or its lack, and point to the need to analyze it in its various aspects.

As there is the experience of handling critical situations related to work health in recycling cooperatives, participative studies are important, because they can promote these workers' visibility, as well as motivating improvements in their quality of life ${ }^{(7)}$. This points to perspectives for nursing in worker health studies, considering that understanding the dynamic between health and work is crucial in order for nurses to act in the construction of action plans directed at vulnerable workers ${ }^{(8)}$.

Moreover, in Brazil and in Latin America, contexts defined by social injustice persist where there are no rights guaranteed for all, with inequalities in income distribution, work, housing, food, and education. Nursing education focused on actions that impact health care in these contexts is a priority. This education should coordinate teaching, care, and research, with a focus on the central problems of this vulnerable population. Currently, nursing education is interested in the dominant attributes and competences that are in line with the necessities of care in all sectors and locations, be they in the sphere of health institutions or $\operatorname{not}^{(9)}$. Therefore, the promotion of research and actions in these unique scenarios creates the possibility of extending nursing care beyond health institutions, reaching populations whose demands are urgent and have rarely been dealt with until now.

In this sense, this study was motivated by the following questions: "What are the elements that promote satisfaction and dissatisfaction in the work of recyclable solid waste segregators? What nursing actions can be performed with a focus on these elements?" Thus, this study's objectives are to describe elements that promote satisfaction and dissatisfaction in the work of recyclable solid waste segregators and conduct a nursing action focused on these elements.

\section{METHOD}

\section{Ethical aspects}

This research was conducted according to Resolution $\mathrm{n}$. $466 / 12$ of the National Health Council. All participants read and signed a free and informed consent form. The research was approved by the local Human Research Ethics Committee.

\section{Study type and methodological frameworks}

This is a qualitative research study of the convergent-care type. Convergent-care research (CCR) proposes an approach focused on nursing care offered in a variety of scenarios. CCR gathers knowledge and practice, uniting assistance and care activities with research production. The method develops throughout five phases: conception (creation and development of the proposal); instrumentation (choice of methodological tools); investigation (data production); analysis; and interpretation ${ }^{(10)}$.

\section{Study setting and participants}

The research was conducted at a recyclable solid waste segregation cooperative in a city in the center region of the state of Rio Grande do Sul, Brazil. This cooperative has existed since the year 1993 and is responsible for solid-waste collection in the city, from homes and establishments registered with the service. It has two trucks for collecting recyclable materials and a warehouse for receiving, separating, and treating materials. Participants were all women who worked in this scenario, totaling 11 workers. There were no inclusion or exclusion criteria. 


\section{Data production}

Data production involved the coordination of three instruments: non-systematic participant observation; semi-structured interviews; and a convergence group.

Non-systematic participant observation ${ }^{(11)}$ occurred across eight days, for a total of 36 field hours, in the month of April, 2015. Aspects concerned the relationship of workers with work organization, task distribution, work dynamics, and interpersonal relationships. The researcher worked along with the participants, sharing some tasks, participating in meals, and seeking dialog. Information obtained each day was recorded in a field diary, which was part of the analysis corpus. Excerpts presented in the results were identified by the acronym ON (Observation Notes), followed by their dates. Concerning the semi-structured interviews, they were conducted during the month of June, 2015, and presented questions referring to social labor data and elements related to the study's objective, lasting 20 minutes on average.

As for the convergence group, it can be defined as a technique that allows research to move together with the care practice, focusing on health education ${ }^{(12)}$. There was a meeting for the proposed objective. It had moments for problematization and discussion among participants, as well as nursing actions operationalized through group dynamics. The meeting happened at the cooperative headquarters in July, 2015, and had a duration of 50 minutes.

The audio of the semi-structured interviews and convergence group were recorded under agreement from all participants and later transcribed, in full, in the text editor Microsoft Windows Word 2010, along with the field diary.

\section{Data analysis}

Data analysis and interpretation followed the stages proposed by the CCR, which consist of: comprehension; synthesis; theorization; and transference ${ }^{(10)}$. Four categories emerged from the analysis process: work that dignifies: experiences of satisfaction; relationship of recyclable solid waste segregators with the work content; experiences of work dissatisfaction: prejudice and interpersonal problems; and recovering individual qualities, building the collective work: nursing action through the convergent-care method.

Segregators were identified in transcriptions by the letter "S" (first letter of the word "segregator"), followed by the number referring to the interview order. Next to each speech identification, the instrument from which it came is referenced. If it is an interview, it's identified by the letter " $\mathrm{I}$ "; if it is the convergence group, it is identified by the initials "CG."

\section{RESULTS}

Concerning age, it was found that the youngest worker was 22 and the oldest was 55 . Six of the 11 workers self-reported as white, three self-reported as dark, and two self-reported as black. Of the 11 workers, eight had children, in a number that ranged from one to eight children per woman. Six segregators had partners. Concerning education, four claimed to have incomplete elementary school education; four had incomplete high school education; one, complete elementary school education; one, complete high school education; and one, incomplete higher education. Concerning the time they were working at the cooperative and in recycling in general, the shortest time was eight months and the longest was 20 years.

Data referring to the categories that emerged from the analysis follow.

\section{Work that dignifies: experiences of satisfaction}

Data reveal elements related to satisfaction and dissatisfaction in the work of women recyclable solid waste segregators. In this category, there are data that point to the identification of the workers with the work they perform:

I like to work here. We have fun, we chat, time goes by quickly. $(\mathrm{S} 4, \mathrm{I})$

[...] I come here, I feel good, I work, I earn my money, I like the girls [...]. $(\mathrm{S} 7, \mathrm{I})$

It was also found that work satisfaction overcomes the low financial compensation.

[...] What I earn does not give me an excellent quality of life, but I feel fulfilled with what I do. I am happy, because, although I earn little money, I am doing something I like [...]. (S11, I)

Other facts that stood out in participants' speeches were the transformations they felt after joining the cooperative:

[...] If I am somebody today, if people know me and respect this work, it is because I learned to do it. [...] The [cooperative] gave me many opportunities. It made me into an actual person. Do you know what it means to be an actual person? I know I am part of something. I am part of an association, of a municipality, of a group of workers that is just beginning to seek recognition. This is good! (S11, I)

Another element that promotes satisfaction with working with recyclable materials concerns what the women achieved through work. They mention feelings of pleasure and work satisfaction resulting from many things, from the fulfillment of basic needs and material acquisitions for the family as well as personal objects related to vanity, according to their speeches:

[...] Now I get to pay my bills, eat better. I eat better [...]. (S6, I)

[...] I could make my house with bricks and mortar. I helped him [partner]; we could buy things for the house. It improved $100 \%$. (S3, I)

[...] Today, when we were receiving a truckload, another worker and I found a bag with perfumes, shampoos, soaps, oils, and body creams with little use, in great shape and of good quality. The worker was very happy with the discovery and quickly put it into her bag [...]. (ON, 04/27/2015)

These data point to the fact that recyclable solid waste segregators experience pleasure in their work through its symbolic content and as result of the positive elements attributed 
to this job by them. Positive elements were also identified in specific tasks, as shown in the following category.

\section{Relationship of recyclable solid waste segregators with the work's content.}

In the cooperative, we observed how affinities for specific divisions of segregation influenced work distribution. Segregators reported affinities for some roles over others. Simultaneously to segregators having affinity for some tasks, they found it hard to adapt to others, which can be a result of individual issues.

What attracts me [in dismantling junk] is finding out that I can dismantle all those things, and if I have to put it back together, I can do it. It is not like computers, which I can use a little and if I have to go back tomorrow and do the same again, I do not remember how I did it. [...] (S11, I)

What I do not like is working on secrecy [name given by the segregators to the process of separating and shredding paper]. The work is very tedious, it does not have a large yield. We separate the paper and it does not yield a lot, it is a lot of work. (S9, I)

An element observed in the speeches of participants concerned the interference of interpersonal relations in task division and how each worker relates to the work content. It was observed that good relationships with others are linked to an affinity for group tasks; otherwise, workers who reported interpersonal problems tend to prefer individual work, as evidenced by these speeches:

We have fun, we chat and time flies by. It is good. I like this, to stay on the table. It is fun. $(\mathrm{S} 4, \mathrm{I})$

Over there [at the shredder] I do not stress over other people. It is quiet over there, just me and the machine; there is no way to stress over anybody. (S1, I)

[...] Where there are too many people, your mind [...] And over there [paper segregation] I just leave at noon; it is just me there. Sometimes they call me and I do not even notice [...] I think, I reflect, and I stay alone. (S2, I)

Data from this category evidenced that personal issues are deeply associated with the identification of workers with their work content. Subjectivity interferes in these interpersonal relationships, which are discussed in the following category.

\section{Experiences of work dissatisfaction: prejudice and inter- personal problems}

Regarding experiences of work dissatisfaction, the perception of prejudice, discrimination, and lack of comprehension from their families and society stand out in the work of segregators. The challenges to recognition that they face begin with their families, in their relationships with their children, according to the excerpt:

[...] My kids were ashamed and I taught them to not be ashamed. [...] He [the son] asked me: "Mother, what do I say at the school? That you are a garbagewoman? I do not want to say that." I told him: "Do not be ashamed, because the food you are eating comes from the trash. If you think it is trash, I do not think it is trash, it is material." So, I taught my family [...]. (S5, I)

Yet, workers reported situations related to discrimination and lack of comprehension from society toward their work:

[...] Some people make us go inside their homes so we can drink some water, but other people do not even let us go past the gate. I think they are afraid; I do not know what they think about us, of this work. (S8, I)

Further concerning experiences with dissatisfaction, interpersonal problems stand out. With this issue, it can be noticed that frictions within the staff are frequently related to extraneous reasons, usually work overload.

[...] At a given moment, I noticed that the women stopped playing and joking, started getting irritated and argued among themselves. I observed, in this aspect, the influence of work overload on their behavior and on interpersonal relationships. Work overload and preoccupation with tasks are manifested by them as irritability, which is frequently exteriorized toward colleagues. (ON, 4/28/2015)

Interpersonal problems affect them in a way that makes them feel their pleasure with work diminish.

Sometimes, we get here feeling great to work and then we see "the faces." Not all of them. It is a minority, a minority of a single person. $(\mathrm{S} 1, \mathrm{I})$

It would be easier if everybody worked well. [...] What is the point in coming here with some types of faces? We arrive so well to work and when we realize everybody is quiet. We also get quiet, so we work a little angry. (S7, I)

[...] Union! It would be easier if people were more transparent. It would be a lot easier. (S10, I)

This body of data shows that interpersonal problems represent critical points for strengthening experiences of pleasure and satisfaction with work. Considering the importance of collective work in coping with the difficulties faced by workers, this demand was chosen to receive a nursing action that employs the convergence group tool.

Recovering individual qualities, building collective work: nursing action through the convergent-care method

Considering the subjectivity of this action's theme and taking into consideration the individuality of each participant (such as difficulty in speaking in public and the tendency to manifest their feelings and opinions timidly and discreetly), the decision was made to conduct this activity through a group dynamic.

Thus, workers sat in a circle and each one received a sheet of paper and a pencil. They were instructed to write their names on the upper part of the sheet and, afterward, pass their sheets 
to the colleague to their right and receive the sheet from the colleague to their left. Then, they were asked to read the name on the sheet and write two qualities they admired about that person. After this movement, the sheets went around again to the right, so that at each round the women would read the name of another colleague and mention two qualities.

This movement was repeated until each paper sheet was returned to its original hands. Then there was a one-minute silent pause for workers to read and reflect on the list of qualities that the colleagues had attributed to them. After the pause, they were asked if they understood the aim of this activity. One of the segregators remarked:

So that each one can know what the others think. Because the sheet has the opinion of each one of us. (S11, CG)

The researcher, then, completed the participant's interpretation, justifying the importance of appreciating collective work:

[...] If you do not support each other and unite, the work will be much harder and you can get ill. I would like you to understand that, despite disagreements, all of you have qualities and lots of good things that you bring to work. I wanted to motivate you to think about each other's qualities, so that you understand that each one of you is special here in different ways. [...] I want each one of you to keep your sheets and think about the compliments given to you by your colleagues. (Researcher)

Workers expressed understanding of the goal of the dynamic, and one of them asked to read aloud the compliments she received. Some of them verbally expressed to the group their feelings at that time.

[...] I wrote it because, for me, she is more than a friend. Because I had a family problem, and I talked to her and she helped me. It was something I thought I would not be able to overcome. I asked her for help and she helped me. (S2, CG)

At the end, there was a collective embrace. The success of the dynamic with the segregators was clear, in the sense that it was possible to conduct a symbolic nursing action that was sensitive and convergent with the theme, occasion, and singular characteristics of the persons involved.

After finishing the nursing actions, there were visitations to the cooperative in order to assess the impacts felt by segregators. It was noticed that, after this action, they brought back their weekly staff meetings, appreciating them as spaces for discussion and conflict resolution. In addition, they also mentioned improvements in interpersonal relationships and attributed those to the qualities dynamics.

\section{DISCUSSION}

The results presented in this article show the elements of work satisfaction among women recyclable solid waste segregators. There were predominant references to feelings of belonging, adaptation, and improvement in life conditions resulting from joining the cooperative. In this sense, the work operates as a mediator of identity construction and self-fulfillment. Thus, it is a health generator as it gives workers feelings of completeness and achievement ${ }^{(13)}$.

It was understood that the segregators found in work an agreement relationship between their material and subjective needs and the benefits afforded by work. It is possible to suppose that the satisfaction of basic life needs, and fulfillment of family and individual plans were demands to be satisfied when they entered the cooperative and that, by having them met through gains from work, they started a process of gratitude and satisfaction with the work.

These results differ from other qualitative studies conducted with recyclable waste segregators, which evidenced that, for participants, dissatisfaction experiences came before satisfaction experiences ${ }^{(4,6)}$. Although acknowledging the low financial gains, these women were satisfied, and this can be the result of the realization of their dreams and aspirations. Thus, a solidarity economy arises as a possibility for income distribution apart from capitalism, focused on those who are excluded from the labor market ${ }^{(6)}$.

It is considered that workers, in their daily experience with work, develop desires and aspirations related to the satisfaction of individuals' needs; thus, work satisfaction is related to the degree to which these desires and aspirations are fulfilled $^{(14)}$. Thus, it can be inferred that working at the cooperative made it possible for these workers to reach personal and family goals and objectives. Be it for their income or for positive aspects subjectively assessed, these elements contribute to the feeling of satisfaction toward work.

Regarding the identification of segregators with the tasks they conduct, the existence of a work organization that enables task division according to individual affinity stands out. In this sense, when work organization enables freedom for routine negotiation and development of each individual's, as well as the collective, singularities it makes it possible for individuals to be active, creative, and autonomous, which can lead to experiences of pleasure. However, when work organization is at odds with individual desires and aspirations and when it ignores their subjectivity, individuals are exposed to experiences of suffering ${ }^{(15)}$.

However, it is important to emphasize that, according to the study's findings, affinity for some tasks is, frequently, related to the degree of adaptation of each worker to the staff and to interpersonal problems, resulting in movements of integration for some and separation for others. Thus, it becomes clear that the cause of pleasure is not, in some situations, the task itself, but the set of elements that is present in the work context of women resulting from performing a given task. The movements of integration and separation among them is one of these elements.

In order for work to be an experience that propels satisfaction and personal edification, it is crucial to transform suffering into pleasure. In this case, pleasure can only be the result of gains obtained from work in regard to the construction of the workers' own identity and self-realization ${ }^{(13)}$.

Therefore, the activity in itself does now allow the transformation of suffering into pain, nor does it produce identity. 
It offers the opportunity to bring the worker and the reality of work together, represented by the regard of the other, by human relationships ${ }^{(13)}$. These considerations lead to the reflection that difficulties in handling interpersonal relationships may be causing not only the isolation of some workers in predominantly solitary tasks, but acting as cause of a possible emptying of work meaning and suppression of pleasurable experiences, of transformative experiences.

From this line of thinking, it was observed that difficulties in handling interpersonal relationships, as well as perceptions of prejudice and lack of appreciation, emerged as the main experiences of dissatisfaction. In relation to this last item, research show that recyclable solid waste segregators frequently perceive themselves as defined by their contact with waste materials, in addition to thinking that society does not recognize the importance of their work, seeing it as a precarious and undignified way to attain an income. They feel discriminated against and feared when their image is associated with theft and alcoholism ${ }^{(16-17)}$.

Regarding the attention the segregators dedicated to interpersonal problems, research conducted with workers in a recycling company showed that, for $57 \%$ of workers, one of the main sources of stress in the workplace is interpersonal relationships ${ }^{(18)}$. These problems have been described in other recent national and international studies carried out with recyclable solid waste segregators ${ }^{(6,19-20)}$. This shows that interpersonal conflicts are also reported in other solid waste segregation scenarios, and may possibly be a common occurrence among these workers.

It is possible to suppose that disagreements in the workplace reflect the exhaustive nature of activities and the frailty in workers' ties. The contemporary forms of work organization, directed by the capitalist regime, value competition and devalue cooperation, resulting in dissolution of collective work $^{(21)}$. This makes workers more fragile, since they cannot count with a collaborative network at the workplace. This fact is, therefore, a relevant element of work satisfaction, since individualism and isolation can stop workers from building relationships of solidarity among themselves.

In line with this, the nursing action that was conducted had the objective of bringing back to the workers a feeling of collective work and the motivation for resolving interpersonal issues. The relevance of this activity resided in the fact that coordination among the segregators is a crucial aspect of building work satisfaction.

In this sense, CCR shines in care practice situations defined as research and practice problems for the construction of innovation in care processes ${ }^{(10)}$. In other words, CCR is an investigation and nursing care method that values reality transformation and health promotion, in line with the principles of autonomy and individual protagonism.

Currently, studies that adhere to the social determinants of the health-disease process and that discuss emerging themes such as vulnerabilities and social risks are prioritized in nursing research, because understanding those themes is crucial for improving people's health and lives ${ }^{(22)}$. The activity conducted with the segregators through group dynamics fulfilled one of the nurses' practice principles, which is based on the promotion of reflection, motivating the critical sense, breaking away from alienation, and focusing on educational activities that promote subjectivity, mental health, and the social and psychic well-being of the people.

Moreover, the activity conducted with the segregators responded to the existing demand in the worker health field that corresponds to the conception that health is absence of accidents and occupational diseases. Thus, understanding that health involves, among other elements, experiences of work pleasure and satisfaction, highlights the potential effect of this activity on the psychic health of segregators. This study also shows the space available for nurses to develop care actions with these individuals, acting in accordance with the necessities of populations that receive little attention from health services.

Nurses, in any practice area, need to constantly reflect on the meaning of their work and functions, as well as on their impact on their own reality. People need professionals committed to defending their rights in a precarious and, frequently, unfair health system, due to complex deficiencies both at local and worldwide levels. One cannot leave behind the interests of nursing and its meanings as a profession; therefore, it is crucial that practice and research be considered in conjunction and committed to the reality of people's life and health ${ }^{(9)}$. In this sense, this study, by bringing together research and nursing practice in a unique context such as that of recyclable solid waste segregators, is viewed as pointing to new possibilities of investigation and action. These possibilities show that advances in nursing research are possible and that there are promising tools such as CCR for the challenge of bringing investigation and care together.

\section{Study limitations}

This study's limitations were difficulties with operationalizing the research, such as access to the cooperative, lack of sanitation at the observation site, and the participants' restricted time availability. However, these limitations did not compromise the quality of the data obtained. Finally, CCR fulfills the demand for bringing together scientific investigation and nursing care practice, creating a convergence relation between researchers and care agents, both represented by nurses ${ }^{(10)}$.

\section{Contributions to the nursing field}

This study's findings contribute to filling in the knowledge and care gaps existing in nursing practice related to vulnerable groups, pointing to a new perspective in the field of qualitative research.

\section{FINAL CONSIDERATIONS}

This research with recyclable solid waste segregators contributed to finding elements that promote satisfaction and dissatisfaction with work. The findings pointed to the close relationship between work and subjectivity, because they showed that work satisfaction is frequently linked to human experience issues, such as the symbolic value of labor and interpersonal relationships. 
Thus, work is a dynamic and paradoxical human experience, simultaneously causing feelings of satisfaction and health and of dissatisfaction and suffering. The authors call attention to the need for nursing to focus on groups such as recyclable solid waste segregators, who are not represented in most of the field's scientific production. The CCR approach also deserves attention as a promising method for simultaneously associating and performing nursing research and care for workers. The CCR approach enables nurses to act as investigators and providers of care, articulating the investigational practice with care actions. This possibility creates more paths for nursing research that is committed to improving life and health.
It must also be considered that this study points to an important element in the construction of human subjectivity: work. Seeing how crucial this domain is for human psychic health, it is crucial for nurses to articulate care actions focused on workers, paying attention to their needs and understanding their feelings in the daily practice of work. These actions are possible through projects of extension, of participative research and health education actions promoted by university research centers and health services.

This research is considered to contribute to new knowledge about workers' health and their work experiences, and opens new perspectives for replication by nurses in other scenarios, employing new methodologies, with the aim of valuing subjectivity.

\section{REFERENCES}

1. Silveira RS, Funck CR, Lunardi VL, Silveira JT, Avila LI, Filho WDL, Vidal DAS. Percepção dos trabalhadores de enfermagem acerca da satisfação no contexto do trabalho na UTI. Enferm Foco[Internet]. 2012[cited 2016 Jan 21];3(2):93-6. Available from: http://revista.portalcofen.gov.br/index.php/enfermagem/article/view/262/150

2. Aazami S, Shamsuddin K, Akmal S, Azami G. The relationship between job satisfaction and psychological/physical health among malaysian working women. Malays J Med Sci[Internet]. 2015[cited 2016 Jan 21];22(4):40-6. Available from: http://www.ncbi.nlm.nih.gov/pmc/ articles/PMC4683848/pdf/mjms-22-4-040.pdf

3. Vazquez JJ. The stigma of making a living from garbage: Meta-sterotypes of trash-pickers in Leon (Nicaragua). Scand J Psychol[Internet]. 2016[cited 2016 Jan 23];57(2)122-8. Available from: http://onlinelibrary.wiley.com/doi/10.1111/sjop.12268/pdf

4. Braga NL, Lima DMA, Maciel RH. "Não tinha trabalho, mas tinha reciclagem": sentidos do trabalho de catadores de materiais recicláveis. Temas Psicol[Internet]. 2015[cited 2016 Jan 24];23(4):1051-9. Available from: http://pepsic.bvsalud.org/pdf/tp/v23n4/v23n4a19.pdf

5. Rolim RS, Teixeira KMD, Fernandes RAU. "Uns valorizam, outros discriminam”: família e sociedade na percepção dos catadores de materiais recicláveis. Oikos[Internet]. 2015[cited 2016 Jan 26];26(1): 205-24. Available from: http://www.seer.ufv.br/seer/oikos/index.php/ httpwwwseerufvbrseeroikos/article/view/211/198

6. Teixeira, KMD. Trabalho e perspectivas na percepção de catadores de materiais recicláveis. Psicol Soc[Internet]. 2015 [cited 2016 Feb 12];27(1):98-105. Available from: http://www.scielo.br/pdf/psoc/v27n1/1807-0310-psoc-27-01-00098.pdf

7. Gutberlet J, Baeder AM, Pontuschka NN, Felipone SMN, Santos TLF. Participatory Research Revealing the Work and Occupational Health Hazards of Cooperative Recyclers in Brazil. Int J Environ Res Public Health[Internet] 2013[cited 2016 Feb 13];10:460727. Available from: http://www.ncbi.nlm.nih.gov/pmc/articles/PMC3823336/pdf/ijerph-10-04607.pdf

8. Coelho APF, Beck CLC, Fernandes MNS, Silva RM, Reis DAM. Organization of the work in a recycling cooperative: implications for the health of female waste pickers. Cogitare Enferm[Internet]. 2016[cited 2016 Feb 13];21(1):01-09. Available from: http:// revistas.ufpr.br/cogitare/article/view/42241/27510

9. Carvalho V. Globalización y competitividad: contexto desafiante para la formación de enfermeira. Esc Anna Nery Rev Enferm[Internet]. 2011[cited 2016 May 10];15(1):171-9. Available from: http://www.scielo.br/pdf/ean/v15n1/24.pdf

10. Trentini M, Paim L, Silva DMGV. Pesquisa Convergente-Assistencial - PCA: delineamento provocador de mudanças nas práticas de saúde. Porto Alegre: Moriá; 2014. 176 p.

11. Spradley JP. Participant observation. New York: Holt, Rinehart and Winston Ed; 1980.

12. Trentini M, Gonçalves LT. Pequenos grupos: um método no desenvolvimento de tecnologias na enfermagem. Texto Contexto Enferm. 2000;9(1):63-78.

13. Lancman S, Sznelwar LI. Christophe Dejours: da psicopatologia à Psicodinâmica do Trabalho. Brasília (DF): Editora Fiocruz; 2011. $507 \mathrm{p}$.

14. Al Magbali MA. Factors that influence nurses' job satisfaction: a literature review. Nurs Manag[Internet]. 2015 [cited 2016 May 10];22(2):30-7. Available from: http://journals.rcni.com/doi/pdfplus/10.7748/nm.22.2.30.e1297

15. Dejours C. Subjetividade, trabalho e ação. Rev Prod[Internet]. 2004[cited May 11];14(3):27-34. Available from: http://www.scielo.br/pdf/ $\mathrm{prod} / \mathrm{v} 14 \mathrm{n} 3 / \mathrm{v} 14 \mathrm{n} 3 \mathrm{a} 03 . \mathrm{pdf}$

16. Miura PO, Sawaia BB. Tornar-se catador: sofrimento ético-político e potência em ação. Psicol Soc[Internet]. 2013 [cited 2016 May 11];25(2):331-41. Available from: http://www.redalyc.org/articulo.oa?id=309328218010 
17. Maciel RH, Matos TGR, Borsoi ICF, Mendes ABC, Siebra PT, Mota CA. Precariedade do trabalho e da vida de catadores de recicláveis em Fortaleza, CE. Arq Bras Psicol[Internet]. 2011[cited 2016 May 11]; 63(esp):71-82. Available from: http://pepsic.bvsalud.org/pdf/arbp/ v63nspe/08.pdf

18. Cislaghi J, Cislaghi TP, Toni M. Estudo do stress no ambiente de trabalho de uma empresa do ramo de reciclagem. Rev Cont Ciênc Gestão Finanças[Internet]. 2015[cited 2016 May 11];3(1):4-20. Available from: http://ojs.fsg.br/index.php/rccgf/article/ view/1458/1337

19. Buque LIB, Ribeiro H. Overview of the selective waste collection with pickers in Maputo municipality, Mozambique: challenges and perspectives. Saude Soc[Internet]. 2015[cited 2016 May 13];24(1). Available from: http://www.scielo.br/pdf/sausoc/v24n1/ en_0104-1290-sausoc-24-1-0298.pdf

20. Ghizoni LD, Mendes AM. Mobilização de um coletivo de catadores: prática em clínica psicodinâmica da cooperação. Cad Psicol Soc Trab[Internet]. 2014[cited 2016 May 13];17(2):206-23. Available from: http://pepsic.bvsalud.org/pdf/cpst/v17n2/ a05v17n2.pdf

21. Dejours C. A sublimação, entre sofrimento e prazer no trabalho. Revista Portuguesa de Psicanálise[Internet] 2013 [cited 2016 May 20];33(2):9-28. Available from: http://sppsicanalise.pt/wp-content/uploads/2014/04/SUBLIMA \%C3\%87\%C3\%83O-ENTRE-SOFRIMENTO-E-PRAZER-NO-TRABALHO.pdf

22. Vale EG, Silva MJ. Research in nursing and new pathways based on SENPE. Rev Bras Enferm[Internet]. 2015[cited 2016 May 20];68(4):5734. Available from: http://www.scielo.br/pdf/reben/v68n4/en_0034-7167-reben-68-04-0571.pdf 